\title{
Bowenoid papulosis: clinical and histological study of eight cases
}

\author{
E GIMENO, J J VILATA, J L SANCHEZ, A LLORET, AND J M FORTEA \\ From the Section of Sexually Transmitted Diseases, Department of Dermatology, Hospital General, \\ Valencia, Spain
}

SUMMARY Eight cases of bowenoid papulosis are reported. The clinical diagnoses were confirmed by histology. In one case an immunoperoxidase method showed the presence of papillomavirus antigen in the nucleus of the most superficial epidermal cells.

We consider bowenoid papulosis to be a condition with specific features that distinguish it clinically and histologically from carcinoma in situ and condylomata acuminata.

\section{Introduction}

In 1977 Kopf and Bart used the term bowenoid papulosis to describe a clinical condition characterised by the appearance of papules in the genital region. ${ }^{1}$ These papules were either discrete or coalesced into plaques, and mainly affected men. The histology was similar to that of carcinoma in situ.

The disease had first been described in 1970 by Lloyd, who called it "multicentric pigmented Bowen's disease". ${ }^{2}$ Various synonyms have been proposed in referring to the clinical characteristics, histology, and probable aetiology of the disease. Friederich called it "reversible vulvar atypia", ${ }^{3}$ whereas Kimura et al described it as "pigmented viral papulosis of the genitals". 4

The most important histological changes described in bowenoid papulosis (loss of cellular polarity, presence of atypical mitoses, and multinucleated atypical keratinocytes with dyskeratosis) were attributed to changes secondary to irritative treatment carried out on benign lesions. ${ }^{5}$ Since the studies by Wade et al in 1978, ${ }^{6}$ however, increased evidence points to the roleof human papillomavirus (HPV) in the aetiology of the disease.

As HPV has been considered as being potentially

Address for reprints: Dr J J Vilata, Section of Sexually Transmitted Diseases, Hospital General, Avenida Tres Cruces, 46014 Valencia, Spain

Accepted for publication 28 June 1986 oncogenic, ${ }^{7}$ careful treatment and observation has been recommended for these patients. Different authors have recommended various treatments, including simple removal with direct suture, electrocoagulation, ${ }^{8}$ topical cytostatic agents, cryotherapy, ${ }^{9}$ and oral administration of aromatic retinoids. ${ }^{10}$ Spontaneous regression has also been reported."

\section{Patients and methods}

During the four years $1982-85$ we diagnosed bowenoid papulosis in eight men, aged between 22 and 50 , who attended the section of sexually tranismitted diseases (STD) of this hospital. Epidemiological characteristics of age, sexual orientation, history of STD, and numbers of sexual partners were stưdied. Paraffin sections of biopsy samples were stained with haematoxylin and eosin, and HPV antigen was looked for with an immunoperoxidase method (PAP Kit K521-025/2; Dakopatts, USA). The sexual contacts of the patients were asked to attend for clinical and, when indicated, histopathological study; the sexual partner of one patient underwent colposcopy.

According to the size or location of the lesion or the patient's preference, treatment consisted of applying liquid nitrogen or $25 \%$ podophyllin resin in alcohol, electrocoagulation, surgical removal, or oral administration of 13-cis-retinoic acid. One patient refused any treatment. All patients were followed up for one to two years. 
TABLE I Epidemiological findings for eight heterosexual men with bowenoid papulosis

\begin{tabular}{llll}
\hline $\begin{array}{l}\text { Case } \\
\text { No }\end{array}$ & Age & $\begin{array}{l}\text { History of sexually } \\
\text { transmitted diseases }\end{array}$ & $\begin{array}{l}\text { No of sexual } \\
\text { partners/year }\end{array}$ \\
\hline 1 & 34 & $\begin{array}{l}\text { Non-gonococcal } \\
\text { urethritis }\end{array}$ & $11-20$ \\
2 & 26 & None & 1 \\
3 & 50 & None & $5-10$ \\
4 & 22 & Syphilis & $3-5$ \\
5 & 43 & Gonorrhoea, syphilis & $3-5$ \\
6 & 28 & Gonorrhoea, syphilis & $6-10$ \\
7 & 30 & None & 1 \\
8 & 24 & Gonorrhoea & 2 \\
\hline
\end{tabular}

\section{Results}

All eight patients were heterosexual men aged 22 to 50 (mean age 32). Five had been treated previously for STD (table I). The clinical lesions, each of several months' duration, consisted of multiple erythematous or hyperpigmented papules, some discrete, located on the shaft of the penis, prepuce, glans, or fraenum, or coalescing to form plaques (figs 1 and 2). None of the patients had local pain or irritation.

\section{FIG 1 Isolated erythematous papules on shaft of penis.}

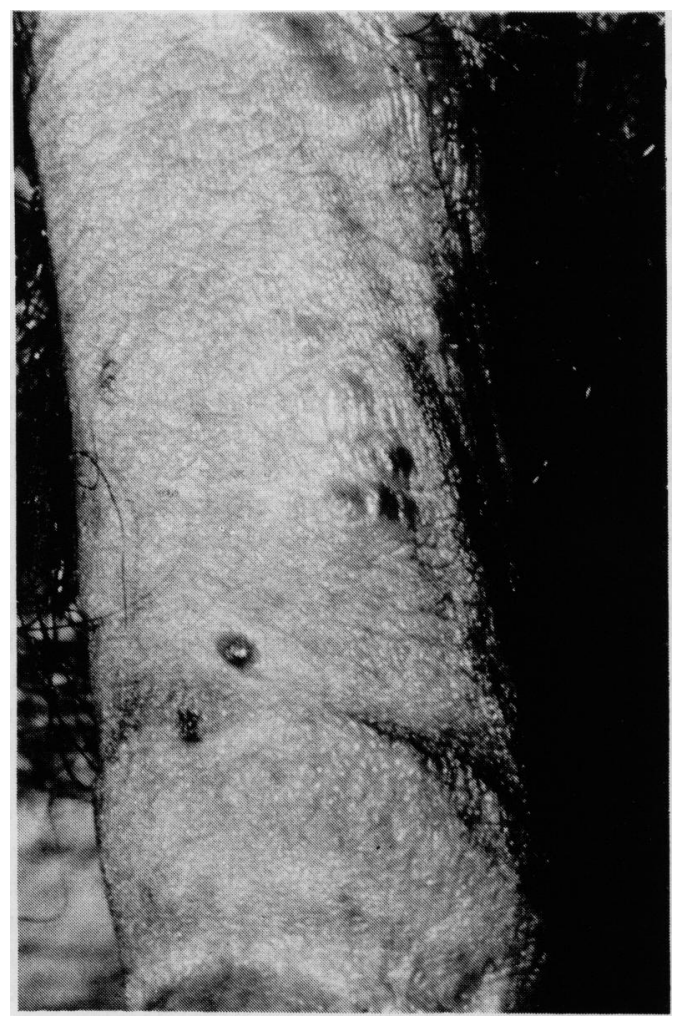

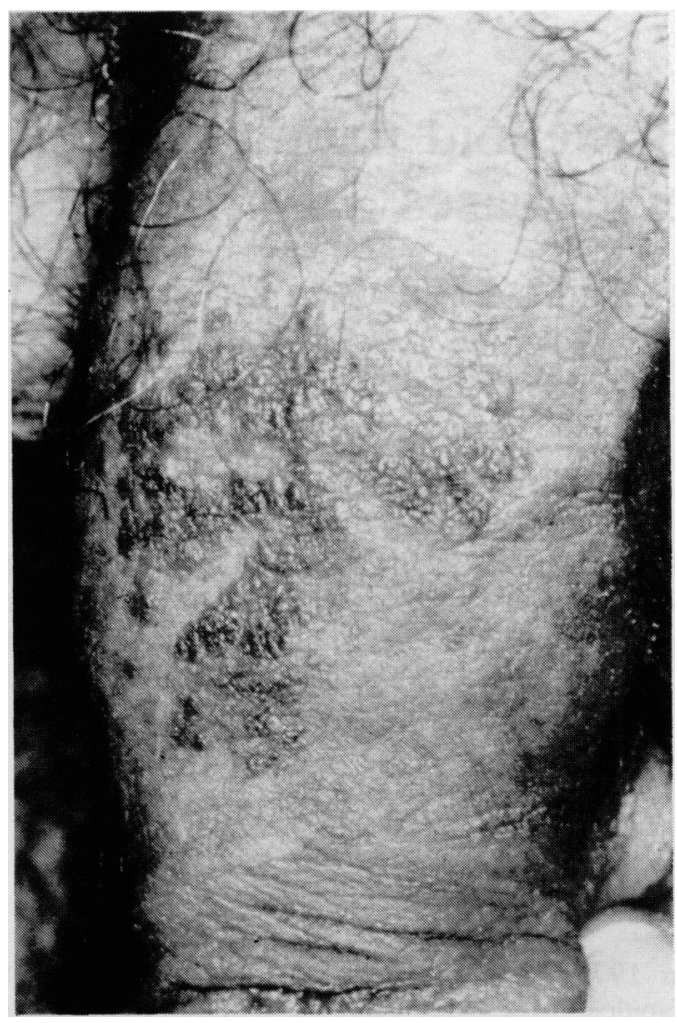

FIG 2 Coalescent verrucose papules into plaques on shaft of penis.

Histological study showed epidermal psoriasiform hyperplasia (fig 3), hyperkeratosis with focal parakeratosis, prominent granulomatous foci, loss of cellular polarity, atypical mitoses, and multinucleated, necrotic, atypical keratinocytes with dyskeratosis (fig 4). At the papillary dermis level, oedema with dilated tortuous capillaries surrounded by a chronic inflammatory infiltrate was observed.

Of the eight biopsy specimens, four presented all the histological characteristics described above; in two of them the stratum granulosum was normal. In one case no multinucleated keratinocytes were found. In the second case the dermal capillaries were not dilated and the dermal inflammatory infiltrate was discrete.

In one case the immunoperoxidase method showed the presence of papillomavirus antigen in the nuclei of the most superficial epidermal cells (fig 5).

Treatment was carried out with 13-cis-retinoic acid in one case, liquid nitrogen in three cases, and simple surgical removal in another. No relapses were observed in these patients during one to two years. In the patient who refused treatment, the lesions regressed spontaneously, reappeared, and disappeared again. In another case, after several relapses after treatment 


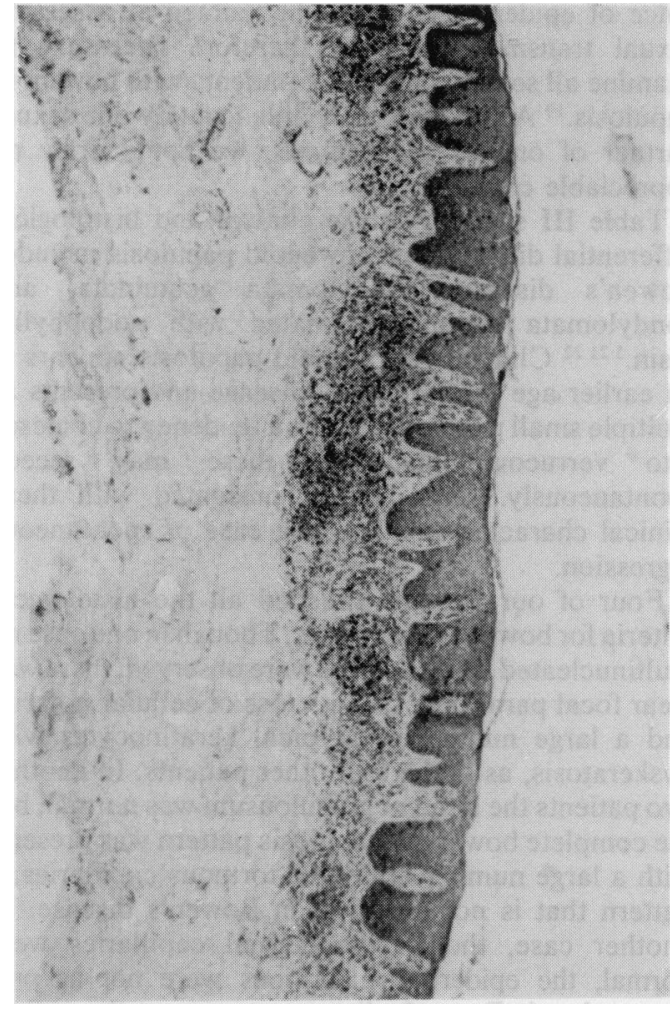

FIG 3 Epidermal psoriasiform hyperplasia. (Haematoxylin and eosin.)

with liquid nitrogen, podophyllin resin was applied without success. The lesions were finally eliminated by electrocoagulation (table II).

The sexual contact of only one of the eight patients attended the clinic. Colposcopy showed plane cervical lesions of HPV. This was confirmed by the histological study of a biopsy specimen of the lesion.

\section{Discussion}

Several different theories on the aetiology of bowenoid papulosis have been advanced; all refer to the action of different irritating factors on primary lesions that in principle are benign. ${ }^{7}$ One of our patients had been treated with podophyllin before being referred to us.

The aetiological role of HPV has been shown by electron microscopy, ${ }^{512}$ though viral particles were only identified in one quarter of cases, possibly because incomplete forms of the virus are not detectable by electron microscopy. ${ }^{6}$ Immunoperoxidase methods have shown the presence of papillomavirus antigen in the nucleus in a small percentage of cases. ${ }^{13}$ In our study this antigen was detected in only one patient, an incidence $(12.5 \%)$ comparable with that reported by Braun et al. ${ }^{13}$ Molecular hybridisation

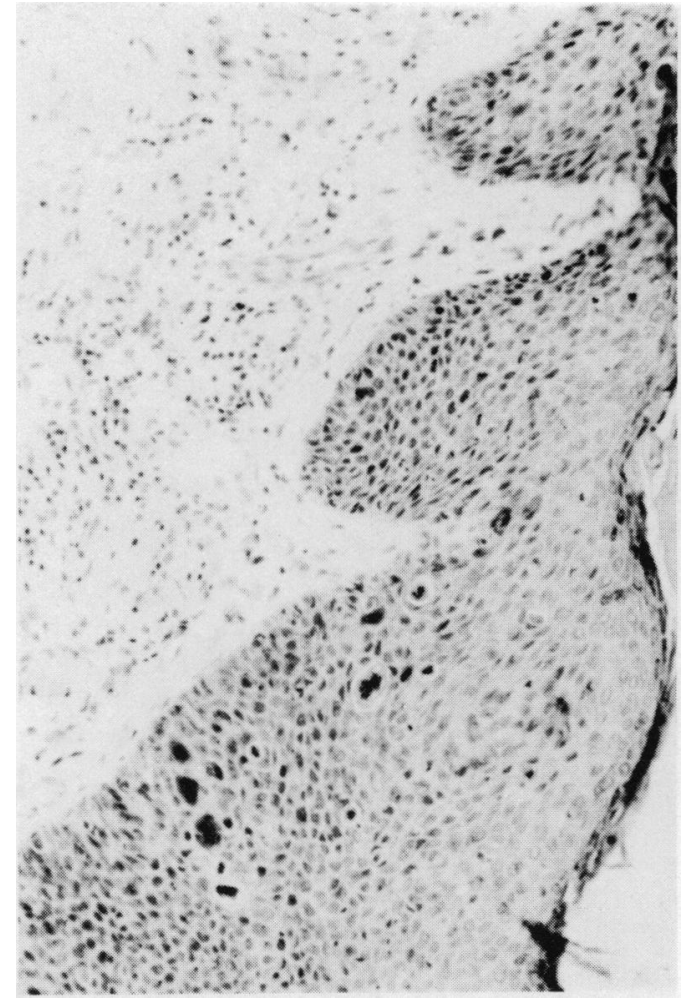

FIG 4 Loss of cellular polarity, atypical mitoses, and multinucleated, necrotic, atypical keratinocytes with dyskeratosis. (Haematoxylin and eosin).

methods have identified HPV in most cases. ${ }^{1416}$ Bowenoid papulosis may be the result of infection with HPV 6, HPV 11, or HPV $16 .{ }^{15}$

Several studies have shown that about 20 to $30 \%$ of patients with carcinoma in situ of the penis or cervix

TABLE II Treatment and follow up of eight men with bowenoid papulosis

\begin{tabular}{llll}
\hline $\begin{array}{l}\text { Case } \\
\text { No }\end{array}$ & Treatment & Relapse & $\begin{array}{l}\text { Period of } \\
\text { follow up } \\
\text { (months) }\end{array}$ \\
\hline 1 & 13-cis-retinoic acid & No & 24 \\
2 & Liquid nitrogen & $\begin{array}{l}\text { No } \\
\text { Spontaneous } \\
\text { remission }\end{array}$ & 23 \\
3 & None & $\begin{array}{l}\text { Relapse } \\
\text { Spontaneous }\end{array}$ & \\
& & remission & 24 \\
& & No & 14 \\
4 & Liquid nitrogen & 22 \\
5 & Surgical removal & No & None \\
6 & Refused & No follow up & 12 \\
7 & Liquid nitrogen & No & \\
8 & Liquid nitrogen & & 11 \\
& Podophyllin resin & & \\
& Electrocoagulation & Several & \\
\hline
\end{tabular}




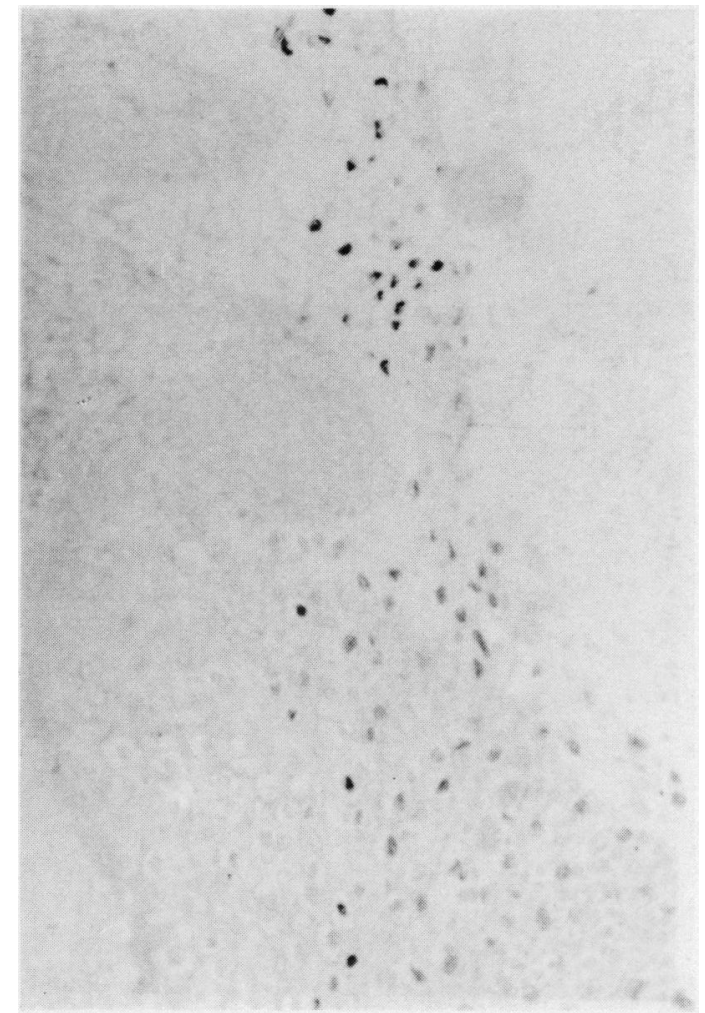

FIG 5 Papillomavirus antigen in nuclei of superficial epidermal cells. Immunoperoxidase method, PAP kit K521-025/2; Dakopatts, USA.)

had previously been treated for condylomata acuminata. ${ }^{1718}$ The recent finding of DNA sequences specific for HPV 16 in cervical dysplasias of women with sexual partners who presented with bowenoid papulosis with HPV 16 sequences shows the impor- tance of epidemiological studies aimed at assessing sexual transmission. It is therefore necessary to examine all sexual partners of patients with bowenoid papulosis. ${ }^{19}$ As we were only able to study one sexual partner of one of our patients, we could draw no appreciable conclusions.

Table III shows that the clinical and histological differential diagnosis of bowenoid papulosis includes Bowen's disease, condylomata acuminata, and condylomata acuminata treated with podophyllin resin. ${ }^{21} 22$ Clinically, bowenoid papulosis appears at an earlier age than Bowen's disease and presents as multiple small papule that have a tendency to coalesce into verrucous plaques; ${ }^{20}$ these may recede spontaneously. Our patients presented with these clinical characteristics and one case of spontaneous regression.

Four of our patients satisfied all the histological criteria for bowenoid papulosis. Though in one case no multinucleated keratinocytes were observed, there was clear focal parakeratosis with loss of cellular polarity and a large number of atypical keratinocytes with dyskeratosis, as in the four other patients. In another two patients the stratum granulousum was normal, but the complete bowenoid papulosis pattern was present, with a large number of dilated tortuous capillaries, a pattern that is not observed in Bowen's disease. In another case, though the dermal capillaries were normal, the epidermal alterations were not as pronounced as in Bowen's disease; moreover, the patient presented with focal hypergranulosis.

There seems to be a relation between bowenoid papulosis and sexual promiscuity. In our group five patients had a history of episodes of STD and considerable sexual activity (table I).

We consider bowenoid papulosis to be a condition with specific characteristics that distinguish it clinically and histogically from carcinoma in situ and condylomata acuminata.

TABLE III Histological differential diagnosis of bowenoid papulosis

\begin{tabular}{|c|c|c|c|c|}
\hline & Bowenoid papulosis & Bowen's disease & Condyloma acuminatum & $\begin{array}{l}\text { Podophyllin treated } \\
\text { condyloma acuminatum }\end{array}$ \\
\hline $\begin{array}{l}\text { Pattern } \\
\text { Stratum corneum } \\
\text { Stratum granulosum }\end{array}$ & $\begin{array}{l}\text { Papulous } \\
\text { Focal parakeratosis } \\
\text { Focal acanthosis }\end{array}$ & $\begin{array}{l}\text { Focal parakeratosis } \\
\text { Normal }\end{array}$ & $\begin{array}{l}\text { Condylomatous } \\
\text { Orthokeratosis } \\
\text { Focal acanthosis }\end{array}$ & $\begin{array}{l}\text { Condylomatous } \\
\text { Haemorrhage }\end{array}$ \\
\hline $\begin{array}{l}\text { Cellular polarity } \\
\text { Keratinocytes: }\end{array}$ & Lost & Lost & Maintained & Maintained \\
\hline Atypical & ++ & +++ & - & + \\
\hline Dyskeratosic & ++ & +++ & - & - \\
\hline Multinucleated & + & ++ & - & - \\
\hline Necrotic & ++ & +++ & - & ++++ \\
\hline Exocytosis & - & - & - & ++ \\
\hline Spongiosis & - & - & - & ++ \\
\hline Dermal capillaries & Dilated \& tortuous & Normal & Dilated \& tortuous & Endothelial proliferation \\
\hline Dermal infiltrate & Lymphohistiocytic & Lymphohistiocytic & Lumphohistiocytic & Neutrophils \& nuclear dust \\
\hline
\end{tabular}

$-=$ none, $+=$ few,$++=$ moderate, $+++=$ abundant, $++++=$ very numerous . 


\section{References}

1. Kopf AW, Bart RS. Multiple bowenoid papules of the penis: a new entity? J Dermatol Surg Oncol 1977;3:265-9.

2. Lloyd KM. Multicentric pigmented Bowen's disease of the groin. Arch Dermatol 1970;101:48-51.

3. Friedrich EG Jr. Reversible vulvar atypia. A case report. Obstet Gynecol 1972;39:173-81.

4. Kimura S, Hira A, Haroda R, Nagashima M. So-called multicentric pigmented Bowen's disease. Report of a case and possible etiologic role of human papiloma virus. Dermatologica 1978;157:229-37.

5. Lupulescu A, Meheregan AH, Homayoon R, Pinkus H, Birmingham DJ. Venereal warts vs Bowen's disease. A histologic and ultrastructural study of five cases. JAMA 1977;237:2520-2.

6. Wade TR, Kopf AW, Ackerman AW. Bowenoid papulosis of the penis. Cancer 1978;42:1890-903.

7. Guillet GY, Braum L, Massé R, Aftimos J, Geniaux M, Texier L. Bowenoid papulosis. Arch Dermatol 1984;120:514-6.

8. Sedel D, Leibowitch M, Pelisse M, Moyal M, Hewitt J. Etats Bowenoides vulvaires de la femme jeune. Ann Dermatol Venereol 1982;109:811-2.

9. Quintanilla E, Temiño MA, Fernández B, Rodrigo A, Olivares C, Tunón T. Papulosis Bowenoids de pene. Actas DermoSifilograficas 1981;72:475-8.

10. Mascaró JM, Torras H, Bou D. Papulosis Bowenoide de los genitales. Comentario sobre su significado. Actas DermoSifilograficas 1980;71:119-28.

11. Eisen RF, Bhawan J, Cahn TH. Spontaneous regression of bowenoid papulosis of the penis. Cutis 1983;32:269-72.
12. Zelickson AS, Prawer SE. Bowenoid papulosis of the penis. Demonstration of intranuclear viral-like particles. Am J Dermatopathol 1980;2:305-8.

13. Braun L, Farmer EV, Shah KV. Immunoperoxydase localization of papiloma virus antigen in cutaneous warts and bowenoid papulosis. J Med Virol 1983;12:187-93.

14. Grosshan S. A propos de la papulose Bowenoide. Les Nouvelles Dermatologiques 1984;4:145.

15. Ikenberg H, Gissmann L, Gross G, Grussendorf-Conen EL, Zur Hausen H. Human papillomavirus type-16-relates DNA in genital Bowen's disease and in Bowenoid papulosis. Int $J$ Cancer 1983;32:563-5.

16. Zachow KR. Detection of human papilloma virus DNA in anogenital neoplasias. Nature 1982;300:771-3.

17. Rotkin I. A comparative review of the epidemiological studies in cervical cancer related to current rearches for transmissible agent. Cancer Res 1973;33:1355-67.

18. Davies SW. Giant condyloma acuminata. Incidence among cases diagnosed as carcinoma of the penis. $J$ Clin Pathol 1965;18:142-9.

19. Egloff H, Gougon N, Franck F, Egloff S. La papulose Bowenoide: á propos de 8 observations personnelles. Gynecologie 1985;36:253-60.

20. Wade TR, Kopf AW, Ackerman AB. Bowenoid papulosis of the genitalia. Arch Dermatol 1979;11 5:306-8.

21. Wade TR, Ackerman AB. The effects of resin of podophyllin on condyloma acuminatum. Am J Dermatopathol 1984;6:109. 22.

22. Kimura $\mathbf{S}$. Condyloma acuminata with pigmented papular lesions. Dermatologica 1980;160:390-7. 